\title{
Active learning across disciplines: opportunities to develop employability skills and leadership potential in undergraduate students. A student and staff perspective
}

\author{
Bell, J., Dicker, R., Garcia, M., Kelly, E., Streich, R., Mulrooney, H and Kelly, A.F*. \\ School of Life Sciences, Pharmacy \& Chemistry, Kingston University, Penrhyn Road, Kingston-upon- \\ Thames, London KT1 2EE.
}

*Corresponding author: a.kelly@kingston.ac.uk

Keywords: Partnership; Active learning; Cross disciplinary; Research; Employability; Leadership

\begin{abstract}
Working effectively within multidisciplinary teams is an important employability skill common in postgraduate working life, but opportunities to develop this are limited in many undergraduate taught programmes. The projects reported here offered twelve level 5 undergraduate students from a range of science disciplines the opportunity to work with each other and staff on a specific research question. This paper explores the experience of cross-disciplinary research from both the student and staff research partners' perspectives. In particular the employability skills gained from such partnership working, the potential for developing and demonstrating leadership skills, and the benefits and disadvantages are discussed.
\end{abstract}

\section{Introduction}

Active learning is viewed as an important aspect of motivating students; a way of engaging students in their learning so that they 'learn by doing' (Chickering \& Gamson, 1987; Bonwell \& Eison, 1991). It provides students with the opportunity to apply newly learned knowledge to practical situations, simultaneously developing and reinforcing many widely recognised employability skills. After university, working within multidisciplinary teams is common, especially in health-related sectors, but this is generally not something students have meaningful experience of before graduation. Indeed, whilst many undergraduates across differing degrees may take a number of shared modules across their programmes there is little opportunity within the formal teaching time to voice ideas, accept others' perspectives and arguments and learn from such peer-to-peer sharing. Students from different degree pathways may view the same knowledge from different perspectives, but opportunities to benefit from such crossdisciplinary peer-learning are often limited by timetable restrictions and the practical difficulties of offering meaningful applied learning opportunities within large modules. The KU Student Academic Development Research Associate Scheme (HEA, 2013) is a university-wide scheme which funds undergraduate student partners for their time during educational development projects ${ }^{1}$. Student and staff partners work together equally on projects which are carried out

1

https://www.heacademy.ac.uk/system/files/sap ca se study 02 kingston new 1.pdf 
Active learning across disciplines: opportunities to develop employability skills and leadership potential

\begin{tabular}{|c|c|c|c|}
\hline Participants & Age, years & Gender, number (\%) & $\begin{array}{l}\text { Ethnicity }{ }^{+} \text {, number } \\
(\%)\end{array}$ \\
\hline Project Year 1 & $\begin{array}{l}\text { Average: } 22.9 \\
\text { Range: } 23-37\end{array}$ & $\begin{array}{c}\text { Male: } 4(67) \\
\text { Female: } 2(33)\end{array}$ & $\begin{array}{l}\text { W: } 5(83) \\
\text { B: } 1(17) \\
\text { A: } 0(0) \\
\text { O: } 0(0)\end{array}$ \\
\hline Project Year 2 & $\begin{array}{c}\text { Average: } 27 \\
\text { Range: } 23-34\end{array}$ & $\begin{array}{c}\text { Male: } 3(50) \\
\text { Female: } 3(50)\end{array}$ & $\begin{array}{l}\text { W: } 5(83) \\
\text { B: } 0(0) \\
\text { A: } 1(17) \\
\text { O: } 0(0)\end{array}$ \\
\hline $\begin{array}{l}\text { Both projects } \\
\text { combined }\end{array}$ & $\begin{array}{c}\text { Average: } 26.7 \\
\text { Range:23-37 }\end{array}$ & $\begin{array}{c}\text { Male: } 7(58) \\
\text { Female: } 5 \text { (42) }\end{array}$ & $\begin{array}{l}\text { W: } 10(83) \\
\text { B: } 1(8) \\
\text { A: } 1(8) \\
\text { O: } 0(0)\end{array}$ \\
\hline
\end{tabular}

Table 1 Descriptive statistics of the student partners by year of participation and for the two years combined. ${ }^{+} \mathrm{W}=\mathrm{White}$; $\mathrm{B}=\mathrm{Black} ; \mathrm{A}=\mathrm{Asian} ; \mathrm{O}=$ Other.

alongside academic commitments, and SADRAS students are funded for their participation. This partnership therefore represented an ideal opportunity for staff and students to work together and to promote both cross-disciplinary active student learning and staff-student collaboration. The specific project funded was an investigation of student perceptions of infection and infection risk, carried out within two separate but related projects with different student partner teams over two years. Over this time, information on the experience of partnership working was collected from student partners, allowing for retrospective analysis from the perspectives of the student and staff research partners involved.

\section{Methods}

\section{Establishing the projects}

SADRAS funding was successfully obtained over two consecutive years for the projects. In both instances they were advertised to undergraduates ( 250 a year) taking a single, level 5 module core to five different degree pathways within the School of Life Sciences, Pharmacy and Chemistry. Ethics approval for the projects was obtained from Kingston University Centre for Higher Education Research \& Practice (CHERP) Research Ethics Committee prior to commencement of the project. The methods used for the investigation into student perceptions of infection and disease risk have been described previously (Abdul Yekeen et al, 2017).

\section{Cross-disciplinary investigations}

At the completion of each project both student and staff partners completed a short questionnaire. This identified their reasons for participation, interest in cross disciplinary working, the challenges involved and what skills they felt they had gained. From this data, the most common themes for both staff and students were identified.

\section{Results}

\section{Student partners}

The demographic details of the student partners are shown in Table 1. The successful applicants were all in their second year. The mix of student partners over the two years comprised BSc Nutrition (4 students), Medical Biochemistry (1 student), Biological Sciences (3 students), Pharmacology and Biomedical Science (1 and 3 students respectively).

\section{Outputs from the research}

The results of the projects on perception and disease risk have been described previously (Abdul Yekeen et al, 2017). Throughout both projects staff and students met on a number of occasions to agree and allocate tasks (Table 2). All tasks required cross-disciplinary negotiation and management, since both projects involved students across a range of 


\begin{tabular}{|l|c|}
\hline \multicolumn{1}{|c|}{ Task } & Responsibility \\
\hline - Completion of project blog & Students \\
\hline - Focus groups & \\
\hline - Questionnaire development & Staff \& students \\
- Docus group guide & \\
\hline - Thematic analysis & Staff \\
\hline - Ethics approval & \\
\hline
\end{tabular}

Table 2 Task description \& responsibility.

\begin{tabular}{|c|c|c|c|}
\hline Theme & Example & Solution/s & $\begin{array}{c}\text { Qualities } \\
\text { demonstrated }\end{array}$ \\
\hline $\begin{array}{l}\text { Time } \\
\text { management }\end{array}$ & $\begin{array}{l}\text { - Managing } \\
\text { SADRAS, } \\
\text { academic, societal, } \\
\text { social \& personal } \\
\text { commitments }\end{array}$ & $\begin{array}{l}\text { - Division of workload. } \\
\text { - Clear } \\
\text { communications. } \\
\text { - Pragmatic acceptance } \\
\text { that inputs into } \\
\text { projects varied over } \\
\text { the life of the project } \\
\text { according to other } \\
\text { commitments (e.g. } \\
\text { assignment } \\
\text { deadlines). }\end{array}$ & $\begin{array}{l}\text { - Organisation. } \\
\text { - Time management. } \\
\text { - Resilience. } \\
\text { - Problem-solving. }\end{array}$ \\
\hline Communications & $\begin{array}{l}\text { Ensuring viable } \\
\text { communications } \\
\text { across six student } \\
\text { and two staff } \\
\text { timetables }\end{array}$ & $\begin{array}{l}\text { - WhatsApp group set } \\
\text { up. }\end{array}$ & $\begin{array}{l}\text { - Communications. } \\
\text { - Problem-solving. } \\
\text { - IT skills. }\end{array}$ \\
\hline $\begin{array}{l}\text { Practicalities of } \\
\text { the project }\end{array}$ & $\begin{array}{l}\text { Distribution of } \\
\text { questionnaires, } \\
\text { organisation \& } \\
\text { operation of focus } \\
\text { groups }\end{array}$ & $\begin{array}{l}\text { - Task allocation using } \\
\text { WhatsApp where } \\
\text { meetings not feasible. } \\
\text { - Shared workload. } \\
\text { - Shared information } \\
\text { regarding timetables \& } \\
\text { availability of different } \\
\text { students for specific } \\
\text { tasks. }\end{array}$ & $\begin{array}{l}\text { - Communications. } \\
\text { - Problem-solving. } \\
\text { - Creativity. } \\
\text { - Resilience. } \\
\text { - IT skills. } \\
\text { - Time management. }\end{array}$ \\
\hline
\end{tabular}

Table 3 The student perspective: major challenges identified in cross disciplinary working, how they were overcome \& qualities demonstrated.

undergraduate degrees, as well as staff with different subject-specific expertise.

Motivations for and challenges in crossdisciplinary working; the student perspective

Half of the student partners $(n=6)$ identified their motivations for involvement, the skills they had gained and how these might be used in the future and the challenges of cross-disciplinary working. The most common motivators for involvement in the projects were the opportunity to work with academic staff and to build professional relationships. 
Active learning across disciplines: opportunities to develop employability skills and leadership potential

\begin{tabular}{|c|c|c|}
\hline Benefit & $\begin{array}{l}\text { Illustrative quote from } \\
\text { student partner }\end{array}$ & Application \\
\hline Gaining work experience & $\begin{array}{c}\text { 'Get a better understanding } \\
\text { of how research is } \\
\text { undertaken' }\end{array}$ & - Future career. \\
\hline $\begin{array}{l}\text { Opportunity to present } \\
\text { work }\end{array}$ & $\begin{array}{c}\text { 'Taking part in a professional } \\
\text { conference' }\end{array}$ & $\begin{array}{l}\text { - Future career. } \\
\text { - PhD research students. }\end{array}$ \\
\hline $\begin{array}{l}\text { Experience of } \\
\text { negotiation \& } \\
\text { communication }\end{array}$ & 'Team working skills' & $\begin{array}{l}\text { - Future career \& viva voce } \\
\text { defence of final year project. } \\
\text { - PhD research student. }\end{array}$ \\
\hline Time management & $\begin{array}{l}\text { 'Setting aside time to do the } \\
\text { work' } \\
\text { 'Working towards deadlines } \\
\text { with others' }\end{array}$ & $\begin{array}{l}\text { - Final year project \& future } \\
\text { career. }\end{array}$ \\
\hline $\begin{array}{l}\text { Experience of } \\
\text { developing activities }\end{array}$ & 'Creating a quiz' & - Future career. \\
\hline $\begin{array}{l}\text { Experience with data } \\
\text { (collection, handling \& } \\
\text { analysis) }\end{array}$ & $\begin{array}{c}\text { 'Additionally I learned data } \\
\text { analysis skills' }\end{array}$ & $\begin{array}{l}\text { - Final year project \& future } \\
\text { career. } \\
\text { - PhD research student. }\end{array}$ \\
\hline $\begin{array}{l}\text { Opportunity to work with } \\
\text { academic staff }\end{array}$ & $\begin{array}{l}\text { 'Liked the idea of working } \\
\text { with my lecturers doing } \\
\text { research, felt it would look } \\
\text { excellent on a CV \& be an } \\
\text { interesting experience' }\end{array}$ & $\begin{array}{l}\text { - Ability to interact with final year } \\
\text { project supervisor. } \\
\text { - Future career. }\end{array}$ \\
\hline
\end{tabular}

Table 4 Key benefits identified by students from participation in the projects.

\section{'Work alongside academic staff \& build professional relationships'}

In addition, having an opportunity to gain tangible research experience and gaining evidence for their Curriculum Vitae were mentioned.

The major challenges identified fell into three major themes, described in Table 3. Students were also asked to describe how they overcame the difficulties they encountered.

The challenges of managing a full academic year alongside the commitments associated with a 10 month research project were the most often cited challenge, followed by communications between students on different degree programmes who did not necessarily share modules or timetables. It was apparent in both student groups that by embracing technology, specifically WhatsApp, they were able to effectively resolve issues of communication and coordination within the group, as well as to know that communications had been received and viewed. This alleviated timetable restrictions whilst allowing student partners to take a pragmatic approach to sharing and organising the workload. One hurdle that required some creative thinking was overcoming a University-imposed moratorium on student surveys at the same time as the research project, which led to the production of quizzes and in-class activities to gather quantitative data as well as focus groups for qualitative data. In addition, although many 
Active learning across disciplines: opportunities to develop employability skills and leadership potential

\begin{tabular}{|c|c|c|c|c|c|c|}
\hline Gender & $\begin{array}{c}\text { Level } 3 \\
(\%)\end{array}$ & $\begin{array}{c}\text { Level } 4 \\
(\%)\end{array}$ & $\begin{array}{c}\text { Level } 5 \\
(\%)\end{array}$ & $\begin{array}{c}\text { Level } 6 \\
(\%)\end{array}$ & $\begin{array}{c}\text { Project } \\
(\%)\end{array}$ & $\begin{array}{c}\text { Degree } \\
\text { average } \\
(\%)\end{array}$ \\
\hline Males & $\begin{array}{c}52.3 \\
(n=2)\end{array}$ & $\begin{array}{c}65.6^{*} \\
(n=7)\end{array}$ & $\begin{array}{l}63.9^{+} \\
(n=7)\end{array}$ & $\begin{array}{c}75.9 \\
(n=5)\end{array}$ & $\begin{array}{c}76.4 \\
(n=5)\end{array}$ & $\begin{array}{c}75.8 \\
(n=5)\end{array}$ \\
\hline Females & $\begin{array}{c}50.9 \\
(n=2)\end{array}$ & $\begin{array}{c}74.1 \\
(n=5)\end{array}$ & $\begin{array}{c}74.1 \\
(n=5)\end{array}$ & $\begin{array}{c}75.0 \\
(n=5)\end{array}$ & $\begin{array}{c}78.0 \\
(n=5)\end{array}$ & $\begin{array}{c}76.0 \\
(n=5)\end{array}$ \\
\hline Both & $\begin{array}{c}51.6 \\
(n=6)\end{array}$ & $\begin{array}{c}69.8^{* *} \\
(n=12)\end{array}$ & $\begin{array}{c}69.0^{++} \\
(n=12)\end{array}$ & $\begin{array}{c}75.4 \\
(n=12)\end{array}$ & $\begin{array}{c}78.0 \\
(n=12)\end{array}$ & $\begin{array}{c}75.9 \\
(n=10)\end{array}$ \\
\hline
\end{tabular}

Table 5 Achievements of student partners by year of study, project module and overall degree average grades. *69.04\% without non-completer $(n=6) ;{ }^{* *} 71.57$ excluding noncompleter $(n=11) .{ }^{+} 67.96 \%$ without non-completer $(n=6) ;{ }^{++} 71.03$ excluding noncompleter $(n=11)$

students identified as willingness to be involved in subsequent focus groups, in reality hurdles were encountered when arranging these by email or other electronic means. An example of the pragmatism demonstrated by the student partners' was to broadcast details of the focus group at a lecture the week beforehand and then escort all those interested in participating directly after the following week's lecture.

\section{What did student partners gain by participation?}

When asked what they had gained from participation, a range of key employability skills and attributes were identified by student partners (Table 4). These included gaining work experience, the opportunity to present in a professional capacity, and experience of negotiation and communication.

Some students thought these skills would be beneficial for their final year project and group assignments whilst others took a longer term view, focusing on the advantages of such skills for their future careers. However, in both instances it was the opportunity to apply the skills they highlighted as beneficial, not just their acquisition.

Most of the students involved have now graduated from the university and their grades and awards achieved are available (Table 5). A total of ten students $(83 \%)$ graduated (one student did not complete his degree and another having completed a sandwich placement in a prestigious institution, is now in his final year). Of the 10 students, $8(80 \%)$ achieved first class honours degrees $(\geq 70 \%$ average), 1 achieved an upper second $(\geq 60 \%$ overall) and 1 achieved a lower second class honours degree ( $\geq 50 \%$ average; $10 \%$ each). Broken down by year of project, in the first year $5(83 \%)$ of the student partners achieved a First class honours degree and in the second year $3(75 \%)$ did so. The percentage of students across the School of Life Sciences, Pharmacy and Chemistry being awarded a first class degree during 2016/7 and 2017/8 was $45 \%$ and $31 \%$ respectively. However, it is appreciated that these were a small sample of self-selecting students that do not reflect both yearly cohorts.

By gender, male achievement was particularly impressive. Whereas the female student partners averaged $>70 \%$ in all years of their degrees, male student partners demonstrated a steady improvement in grades throughout their time at university. The jump in average grades from Levels 5 to 6 was particularly impressive; Level 5 is often experienced as the most difficult year of study and this was also the year when these students undertook the additional SADRAS research project. For both male and female student partners, the jump in achievement from Level 3 was also impressive. Both groups averaged $\sim 50 \%$ in Level 3 but graduated with averages $>70 \%$. This suggests that predicting student attainment on the basis of performance at Level 3 in this cohort would have been highly inaccurate, underestimating actual achievements. In addition it may illustrate the value of the foundation year in preparing students for university life and it may 


\begin{tabular}{|c|c|c|c|c|}
\hline Student & $\begin{array}{l}\text { Project } \\
(\%)\end{array}$ & $\begin{array}{l}\text { Viva } \\
(\%)\end{array}$ & $\begin{array}{l}\text { Thesis } \\
(\%)\end{array}$ & Current status \\
\hline $1^{*}$ & 85 & 90 & 84 & Studying postgraduate medicine \\
\hline $2^{*}$ & 81 & 80 & 81 & PhD student \\
\hline $3^{*}$ & 95 & 100 & 97 & $\begin{array}{l}\text { PhD student (did additional prestigious } \\
\text { placement between Levels } 5 \& 6 \text { ) }\end{array}$ \\
\hline 4 & 61 & 64 & 61 & Applying for MSc after gap year \\
\hline 5 & 75 & 72 & 76 & MSc student (Nursing) \\
\hline 6 & 60 & 65 & 59 & No data \\
\hline $7^{*}$ & 76 & 75 & 79 & Gap year \\
\hline $8^{* \dagger}$ & $\begin{array}{l}\text { Currently } \\
\text { Level } 6\end{array}$ & $\begin{array}{l}\text { Currently } \\
\text { Level } 6\end{array}$ & $\begin{array}{l}\text { Currently } \\
\text { Level } 6\end{array}$ & $\begin{array}{l}\text { Did additional prestigious placement between } \\
\text { Levels } 5 \& 6\end{array}$ \\
\hline 9 & 95 & 95 & 95 & Masters by research \\
\hline 10 & 74 & 70 & 75 & Research technician \\
\hline 11 & 82 & 90 & 84 & No data \\
\hline 12 & $\mathrm{n} / \mathrm{a}$ & $\mathrm{n} / \mathrm{a}$ & $\mathrm{n} / \mathrm{a}$ & Withdrew at end of Level 5 \\
\hline
\end{tabular}

Table 6 Individual achievements of student partners within the final year project module elements and post-graduation. *Student partners who invested most in the projects. ${ }^{\dagger}$ Student partner involved in second project who went on to undertake a placement year and yet to graduate at time of submission.

be that some of the skills and attributes inculcated at Level 3 were only applied as students progressed through their university degrees.

Achievements in the final year project module, mentioned by some student partners as their reason for participating in the SADRAS project, were equally impressive. Average grades achieved in this independent project were first class honours for both male and female student partners. This is noteworthy since the project module represents one of the first opportunities for independent research for most undergraduate students.

Unsurprisingly within this high-achieving group, their success has continued since graduation. Individual data from student partners demonstrates that of the 10 students from the project who have graduated so far, 6 are studying at postgraduate level, 2 for PhD's (Table 6).

\section{Challenges with cross-disciplinary working; the staff perspective}

In many respects, challenges identified by staff mirrored those experienced by the student partners. Although both staff members were part of the same department (Applied and Human Sciences), they lectured on different subjects to different cohorts of undergraduates which resulted in conflicting timetables. However staff tended to use e-mail rather than WhatsApp as their technical solution. This was because the use of email was already embedded in day-to-day practice and work mobile phones are not supplied. Additionally, meetings to identify important issues and when appropriate to divide the workload/ or step in where necessary were frequent and informal but often in the early morning (prior to lecturing), fleeting in nature and occasionally held as 'corridor conferences' in passing. Perhaps because of their brevity and the differing professional experience and viewpoints of the staff concerned, the outcomes of the project demonstrate their 
Active learning across disciplines: opportunities to develop employability skills and leadership potential

productive nature. To date, two papers have been published from the projects, two poster presentations given and three presentations at national teaching and learning conferences.

Practical management of the project was challenging. Booking meeting rooms during the busy term at times that suited focus groups, provision of refreshments with no project consumables and liaising with module leaders to organise the distribution of the in-class activity, as well as meeting with the student partners while carrying out normal academic work presented real time pressures. Like the students, staff adopted a pragmatic approach, dividing the work according to their availability and accepting that individual input into the project would fluctuate depending on other demands (e.g. teaching, marking, research, administration \& pastoral care).

At the end of each project, staff also reflected upon what they gained over the process. Although already accustomed to juggling multiple commitments, time management and the practicalities of managing the partnership were highlighted as key learning points. Both had experience of project management within their subject disciplines, but not within pedagogy. There was however, a reflection not to overestimate what was possible over the lifetime of the projects as both staff involved had numerous academic responsibilities (course directorship, programme organiser of co-curricular events, undergraduate and postgraduate project supervision). Notwithstanding, it was very rewarding not only to work together but also to have had the opportunity to work with 12 engaged students. Project working is by its nature creative, but this experience enabled staff to watch a disparate group of students come together and problem solve, gaining ownership within the two projects.

\section{Discussion}

In this paper we review the challenges of crossdisciplinary working experienced by staff and self-selecting students from different degree routes at Kingston University who became involved in two relatively lengthy pedagogical research projects. From this, a number of themes emerged which will be discussed in turn.

\section{Differences in approach to similar problems by staff and students}

The challenges faced in the projects and how these were overcome, highlighted a difference in working patterns between staff and student partners. Although many of the same challenges occurred in both groups, the methods adopted to overcome them varied. For example, although staff and students used technology to manage day-to-day communications, both the technology of choice and its frequency of use differed. The willingness of the student partners to embrace digital technology as a tool highlights potential differences in digital fluency between the students and staff involved. Staff partners used digital technology in the form of e-mail as well as face-to-face meetings to disseminate information; the former for secure sharing of information and files and the latter for speed and creative problem-solving. The use of digital applications and media within higher education settings is increasing with the advantage of overcoming physical hurdles being a main driver (Sevillano-Garcia and Vazquez-Cano, 2014). Although the choice of specific technologies was driven by the students themselves, it has been suggested that technology and making connections should be included as learning activities as part of a shift towards a digital age (Siemens, 2005).

\section{Emergence of natural leaders}

Participation in SADRAS projects requires sustained effort by staff and students as they run across a full academic year, additional to taught modules. To ensure continued motivation and enthusiasm for the project, a self-selection procedure to identify six student partners each year was used. In both years, a group of students became more heavily invested in the project, and drove the distribution of activities, data analysis and production of conference materials by investing significant personal time in the work. It seemed that this opportunity allowed natural leaders to emerge from the student pool, enhancing their leadership, negotiation skills and confidence. The other students, while maintaining their involvement in the project, were less committed, unwilling to invest additional unremunerated personal time in it. While this may seem discouraging, it suggests that involvement in this work with all its inherent difficulties motivated a third of student partners 
to see beyond the subject of the projects to the short and long term advantages that accrue to partnership working. The other less committed students were still able to gain skills from the experience of working with others in a shared endeavour, albeit to a lesser degree. Leadership skills can be developed (Kouzes \& Posner, 2007), and higher education is recognised as an important time for developing them in young people (Pascarella \& Terenzini, 2005; Astin \& Astin, 2000; Morse, 1989). Leadership skills have been identified as a combination of professional and personal qualities including self-reliance, pragmatism, a sense of personal responsibility, flexibility and communication skills (Alimbehova et al, 2016), at least some of which were identified by student partners in this work as skills they had gained from their participation (Table 4).

\section{Development and recognition of employability skills}

Retrospective analysis of student partner experience clarified their recognition that project involvement offered them opportunities to develop, expand on and apply employability skills. Some of the skills they identified from their involvement in the project group included creativity, communication, time management, dependability, organisation, resilience and pragmatism, all of which are important qualities both for team work and future employability (Cranmer, 2007; Overtoom, 2000), and highlighted by the HEA graduate skills attributes framework (HEA, n.d.). Student partner feedback clarified that they could see the benefits both within the short-term (applied to their final year in academia) and in the longer term (applied to their future careers), and this has been borne out by their career paths since graduation (Tables 4 \& 6).

\section{Opportunity for extended active learning, linked to the development and application of employability skills}

Problem-solving within each project was approached by allowing the students to initiate it, engendering feelings of commitment and autonomy whilst also developing their creativity and resilience. The development of autonomy linked to active learning and emergence of leadership skills was also seen by Middleton (2013) in work with undergraduate nursing students and in work by Power (2012), albeit through the introduction of a specific taught module. In our case, the experiences were delivered during an extracurricular activity (ECA), one of many available to undergraduates at Kingston University.

It is assumed that ECAs, non-academic experiences affording 'life-wide learning' (Jackson, 2011 as cited by Thompson et al, 2013), are positive experiences for undergraduates promoting social and employability skills required for postgraduate life. Whilst not all graduates will use their subject-specific knowledge after university, many employers expect them to have qualities including the ability to communicate, integrity, confidence and personality (Archer and Davison, 2008), as well as a capacity to reflect, fundamental to working in a team (Hinchcliffe and Jolly, 2011). Previous research has shown that the personal qualities of graduates are rated highly by employers as markers of academic quality (Dicker et al, 2018). However whilst Thompson et al (2013) found that the majority $(80 \%)$ of students they surveyed recognised that their ECAs could have career benefits, they also identified instances where ECA engagement negatively affected academic study (conflicting time requirements and responsibilities). It is paramount that staff are realistic in terms of goals and objectives in active learning opportunities such as SADRAS research projects, to ensure that student partners enjoy the whole experience alongside their taught curriculum, without encroaching on their ability to succeed academically. It is also important that students use opportunities such as ECAs to learn to cope with conflicting priorities and time management, skills which will benefit them not just in their careers, but which are essential life skills.

\section{The opportunity to work closely with academic staff}

Student partners identified being able to work closely with staff partners as one of the main reasons they got involved. Students have been shown to value relationships with academics most highly followed by interactions with their peers (Dicker et al, 2017), when identifying markers of what constitutes high quality higher education. The integration of staff research into undergraduate student teaching is quite commonplace in higher education, although undergraduate and postgraduate views on such can be both positive and negative 
(Lindsay et al, 2002). What these projects offered was an opportunity for students to be involved in developing and undertaking that research as equal partners. The importance of a safe and informal learning environment which includes supervision time, observation and feedback has been highlighted by research with medical students (van der Zwet et al, 2011). Being allowed to be a learner whilst being simultaneously feeling accepted and respected as individuals contributes to the concept of legitimate participation (Lave and Wenger, 1991). Involvement with staff including one-to-one supervision and feedback has been shown to increase feelings of confidence and competence in learners (O'Sullivan et al, 2000), unsurprising if learning is viewed as a social process, occurring by participation within a community of practice (Lave and Wenger, 1991). Learning depends both on the nature of the activities undertaken and the meaning attached to them (Mann et al, 2010); students learn by doing (van der Zwet et al, 2011). Teachers create the conditions in which learning is possible, so the involvement of staff in active learning opportunities is essential (Mueller \& Fleming, 2001). In the case of this project both the involvement of staff and the specific tasks undertaken were specifically valued by students (Table 4 ).

\section{Benefits of involvement for the future}

Russell et al (2007) investigated the benefits of undergraduate research experiences of almost 15,000 respondents in the USA, finding that many fuelled interest in STEM careers and higher degrees. We did not specifically ask if our student partners were thinking about higher degrees, although all twelve were studying STEM degrees. However the data in Table 6 demonstrates that many within this student cohort have done so and two in addition undertook additional sandwich placement years in prestigious research departments. This suggests that the skills and benefits gained from involvement in the projects would be equally as beneficial to the attainment of higher degrees as to future employment. Clearly these students gained from their involvement in the projects. However it could be argued that because they were already ambitious and high achieving, they were able to see the benefits of such involvement. It is noteworthy that the female student partners were high achievers all the way through their degree programmes, after an initial jump in grades from Level 3 to Level 4 (Table 5). The same was not true for the male student partners, who instead showed a steady increase in attainment. The subject of male attainment within higher education is of increasing interest since females are now 35\% more likely to enter higher education than males (HESA, 2016), and are more likely to gain better degrees than their male counterparts (Woodfield, 2014; HESA, 2016). There are many possible reasons for this including the possibility that male students may overestimate their likely attainment (Cotton et al, 2015), study for fewer hours than female students (Cotton et al, 2015; OECD, 2015), play more collaborative online games (OECD, 2015) and read less for enjoyment (OECD, 2015). Ensuring that male attitudes and personal aspirations towards learning are boosted therefore represents an important challenge for higher education in order to address this attainment gap (Hillman \& Robinson, 2016). This cohort of male students were clearly capable and attained very highly but it may also be that the authentic learning opportunity offered by these projects particularly benefitted male students.

We recognise that these projects offered unique opportunities to explore crossdisciplinary working from staff and student perspectives. However the opportunities for undergraduate students to engage in lengthy cross disciplinary project work of this nature are necessarily limited within the undergraduate curriculum. However the diverse university environment offers many opportunities to gain and demonstrate evidence of key graduate attribute and employability skills (HEA, 2015). Alternatives may include being a course representative, working as student ambassadors and volunteering.

\section{Conclusions}

During these two opportunities for students and staff to participate in pedagogic research, it was interesting to note that the challenges experienced were broadly similar to both groups, although differing solutions were seen.

Unforeseen obstacles provided unexpected opportunities for student creativity, and the 
Active learning across disciplines: opportunities to develop employability skills and leadership potential

project itself allowed student partners to develop individual autonomy as well as appreciate the highs and lows of team working. Reflections upon these active learning experiences highlighted a range of important skills and competencies gained by students. Involvement in this active learning opportunity allowed the emergence of natural leaders, who demonstrated ownership over the project and have since demonstrated high levels of achievement in their postgraduate lives. Whilst this paper is based upon relatively small numbers, both projects were relatively lengthy allowing a good depth of reflective analysis on the parts of both staff and student partners on their involvement in active learning opportunities as well as the approaches used by both.

\section{Acknowledgments}

The authors would like to acknowledge all student partners involved in both research projects.

\section{References}

Abdul Yekeen, A.F., Bell, J., Boorman, A., Hancock, C., Kelly, A., Kelly, E., Mulrooney, H.M., \& Streich, R. (2017) Exploring student perceptions of health and infection: an interactive staff and student partnership scheme. New Directions in the Teaching of Physical Sciences, 12 (1). DOI: 10.29311/ndtps.v0i12.596.

Alimbehova, A., Asylbekova, M. \& Karimova, R. (2016) Development of Leadership Potential in Students within an Education Space of a Pedagogical University. Int J Env Sci Educ 11 (11): 4610-4616. ISSN: EISSN-1306-3065

Archer, W. \& Davison, J. (2008) Graduate Employability: the Views of the Employers. London: The Council for Industry and Higher Education (CHIE). Available at https://www.brunel.ac.uk/_data/assets/pdf_fil e/0009/92718/CIHE__0802Grademployability1.pdf

Astin, A.W. \& Astin, H.S. (2000) Leadership reconsidered: Engaging higher education in social change. Battle Creek, MI: WK Kellogg Foundation. ERIC Number: ED444437
Bonwell, C.C. \& Eisen, J.A. (1991) Active Learning: Creating excitement in the classroom. ASHE-ERIC Higher Education Reports. Available at:

https://files.eric.ed.gov/fulltext/ED336049.pdf.

Chickering, A.W. \& Gamson, Z.F. (1987) Seven Principles for Good Practice. AAHE Bulletin 39: 3-7. Available at

https://files.eric.ed.gov/fulltext/ED282491.pdf

Cotton, D.R.E., Joyner, M., George, R. \& Cotton, P.A. (2015) Understanding the gender and ethnicity attainment gap in UK higher education. Innovations in Education and Teaching International. DOI: 10.1080/14703297.2015.1013145

Cranmer, J. (2007) Enhancing graduate employability: best intentions and mixed outcomes. Studies in Higher Education 31(2): 169-184. DOI: 10.1080/03075070600572041

Dicker, R., Garcia, M., Kelly, A., Modabber, P., O'Farrell, A., Pond, A., Pond, N. \& Mulrooney, H.M. (2017) Student perceptions of quality in higher education: effect of year of study, gender and ethnicity. New Directions in the Teaching of Physical Sciences, 12 (1). DOI: 10.29311/ndtps.v0i12.2332

Dicker, R., Garcia, M., Kelly, A. \& Mulrooney, $\mathrm{H}$. (2018) What does 'quality' in higher education mean? Perceptions of staff, students and employers, Studies in Higher Education. DOI: $10.1080 / 03075079.2018 .1445987$

Higher Education Academy Students as Partners Change Programme. (2013) Student Academic Development Research Association Scheme (SADRAS). Available at https://www.heacademy.ac.uk/system/files/sa p_case_study_02_kingston_new_1.pdf

Higher Education Academy (2015) Framework for Embedding Employability in Higher Education. Higher Education Academy: York. Available at:

https://www.heacademy.ac.uk/system/files/do wnloads/embedding-employability-in-he.pdf

Higher Education Academy (nd) Graduate skills attributes framework. Higher Education Academy: York. 
Active learning across disciplines: opportunities to develop employability skills and leadership potential

HESA (2016) Higher education student enrolments and qualifications obtained at higher education providers in the United Kingdom 2014/15. Statistical First Release 224. Available from: https://www.hesa.ac.uk/news/14-01-

2016/sfr224-enrolments-and-qualifications

Hillman, N. \& Robinson, N. (2016) Boys to Men: The underachievement of young men in higher education - and how to start tackling it. HEPI Report 84. Higher Education Policy Institute: Oxford. Available from: https://www.hepi.ac.uk/wp-

content/uploads/2016/05/Boys-to-Men.pdf

Hinchcliffe, G.W. \& Jolly, A. (2011) Graduate identity and employability. British Educational Research Journal 37(4): 563-84. DOI: 10.1080/01411926.2010.482200

Jackson, N. (2011) Recognising a more complete education through a Lifewide Learning Award. Higher Education, Skills and Work-Based Learning 1(3): 247-61. DOI: $10.1177 / 1469787415574050$

Kouzes, J. \& Posner, B. (2007) The Leadership challenge. $4^{\text {th }}$ edition. Jossey-Bass: San Francisco. ISBN: 0470651725.

Lave, J. \& Wenger, E. (1991) Situated learning: Legitimate peripheral participation. Cambridge: Cambridge University Press.

Lindsay, R., Breen, R. \& Jenkins, A. (2002) Academic research and thinking quality: the views of undergraduates and postgraduate students. Studies in Higher Education 27(3): 309-27. DOI: 10.1080/03075070220000699

Middleton, R. (2013) Active learning and leadership in an undergraduate curriculum: How effective is it for student learning and transition to practice? Nurse Education in Practice 13: 83-88. DOI: 10.1016/j.nepr.2012.07.012.

Morse, S.W. (1989) Renewing civic capacity: Preparing college students for service and citizenship. ASHE-ERIC Higher Education Report No 8. Washington DC: George Washington University.
Mueller, A. \& Fleming, T. (2001) Cooperative learning: listening to how children work at school. Journal of Educational Research 94 (5), 259-265. DOI: $10.1080 / 00220670109598761$

OECD (2015) The ABC of Gender Equality in Education: Aptitude, Behaviour, Confidence. PISA: OECD Publishing. DOI: 10.1787/9789264229945-en

O'Sullivan, M., Martin, J. \& Murray, E. (2000) Students perceptions of the relative advantages and disadvantages of communitybased and hospital-based teaching: $A$ qualitative study. Medical Education 34: 648655. DOI:10.1046/j.1365-2923.2000.00623.x

Overtoom, C. (2000) Employability skills: an update. ERIC Digest 22: 1-6. https://files.eric.ed.gov/fulltext/ED445236.pdf

Pascarella, E. \& Terenzini, P. (2005) How college affects students (Vol 2): a third decade of research. San Francisco: Jossey Bass. ISBN: 978-0-787-91044-0

Power, J. (2012) Promoting employability skills through active learning. In: The Second Employability, Enterprise and Citizenship in Higher Education Conference, Tuesday $27^{\text {th }}$ March 2012, Manchester. http://eprints.hud.ac.uk/id/eprint/16613/

Russell, S.H., Hancock, M.P. \& McCullough, J. (2007) Benefits of undergraduate research experiences. Science 316: 548-9. DOI: 10.1126/science.1140384

Siemens, G. (2005) Connectivism: A learning theory for the digital age? International Journal of Instructional Technology and Distance Learning 2 (1). ISSN 1550-6908.

Thompson, L.J., Clark, G., Walker, M. \& Whyatt, J.D. (2013) 'It's just like an extra string to your bow': exploring higher education students' perceptions and experiences of extracurricular activity and employability. Active Learning in Higher Education 14(2): 135-47. DOI: 10.1177/1469787413481129

Sevillano-Garcia, M.L. \& Vazquez-Cano, E. (2015) The impact of digital mobile devices in Higher Education. The Journal of Educational 
Active learning across disciplines: opportunities to develop employability skills and leadership potential

Technology and Society 18 (1): 106-118. ISSN: 14364522

van der Zwet, J., Zwietering, P.J., Teunissen, P.W., van der Vleuten, C.P.M. \& Scherpbier, A.J.J.A. (2011) Workplace learning from a socio-cultural perspective: creating developmental space during the general practice clerkship. Adv in Health Sci Educ 16: 359-373. DOI: 10.1007/s10459-010-9268-x.
Woodfield, R. (2014) Undergraduate retention and attainment across the disciplines. Higher Education Academy: York. Available from: https://www.heacademy.ac.uk/system/files/res ources/undergraduate_retention_and_attainm ent_across_the_disciplines.pdf 